\title{
Community benefits from offshore renewables: The relationship between different understandings of impact, community, and benefit
}

\section{Rudolph, David Philipp; Haggett, Claire; Aitken, Mhairi}

\section{Published in:}

Environment and Planning C: Government and Policy

Link to article, DOI:

$10.1177 / 2399654417699206$

Publication date:

2018

Document Version

Peer reviewed version

Link back to DTU Orbit

Citation (APA):

Rudolph, D. P., Haggett, C., \& Aitken, M. (2018). Community benefits from offshore renewables: The relationship between different understandings of impact, community, and benefit. Environment and Planning $C$ : Government and Policy, 36(1). https://doi.org/10.1177/2399654417699206

\section{General rights}

Copyright and moral rights for the publications made accessible in the public portal are retained by the authors and/or other copyright owners and it is a condition of accessing publications that users recognise and abide by the legal requirements associated with these rights.

- Users may download and print one copy of any publication from the public portal for the purpose of private study or research.

- You may not further distribute the material or use it for any profit-making activity or commercial gain

- You may freely distribute the URL identifying the publication in the public portal 


\title{
THE UNIVERSITY of EDINBURGH
}

\author{
Edinburgh Research Explorer
}

\section{'Community Benefits from Offshore Renewables'}

\section{Citation for published version:}

Haggett, C, Quiroz-Aitken, M \& Rudolph, D 2018, "Community Benefits from Offshore Renewables': The relationship between different understandings of impact, community and benefit', Environment and Planning C: Politics and Space, vol. 36, no. 1, pp. 92-117. https://doi.org/10.1177/2399654417699206

\section{Digital Object Identifier (DOI):}

10.1177/2399654417699206

Link:

Link to publication record in Edinburgh Research Explorer

Document Version:

Peer reviewed version

Published In:

Environment and Planning C: Politics and Space

\section{General rights}

Copyright for the publications made accessible via the Edinburgh Research Explorer is retained by the author(s) and / or other copyright owners and it is a condition of accessing these publications that users recognise and abide by the legal requirements associated with these rights.

\section{Take down policy}

The University of Edinburgh has made every reasonable effort to ensure that Edinburgh Research Explorer content complies with UK legislation. If you believe that the public display of this file breaches copyright please contact openaccess@ed.ac.uk providing details, and we will remove access to the work immediately and investigate your claim. 


\section{Community Benefits from Offshore Renewables: The relationship between different understandings of impact, community, and benefit}

\section{Introduction}

This paper reports on a project commissioned for the Scottish Government evaluating community benefit models for offshore renewables. Whilst community benefits are well established for renewable energy projects onshore, they are rare for offshore developments, anywhere in the world. Consequently, very little is known about the most appropriate ways in which they might be implemented (or whether they are appropriate at all). We specifically address this knowledge gap, and draw out the significance for this emerging policy area. To do so we identify existing types of community benefits and explore the intricate relationship between different understandings of benefits, communities, and impacts underlying various visions of how community benefits from offshore renewables can be delivered.

Consideration of community benefit models for offshore developments has particular significance for Scotland, which has extensive offshore wind, wave, and tidal resources and ambitious policy targets for the generation of energy from renewable sources. Further, the Scottish Government is alone in explicitly considering distribution of the local and national benefits beyond the delivery of supply chain benefits from offshore renewables (Scottish Government, 2015). But the consideration of community benefits has far wider resonance. International research has demonstrated that renewable energy developments have routinely experienced political, planning, and public acceptance challenges (Toke et al, 
2008). Moreover, research has identified that similar challenges occur both on- and offshore (Haggett, 2008; 2010a). Vocal and effective protests against offshore renewables have been well documented (Firestone et al., 2009; Devine-Wright and Howes, 2010; Haggett 2008; Todt et al., 2011), necessitating a focus on issues of social acceptance. The delivery of community benefit schemes has become well established for onshore renewables (Aitken, 2010b; Cowell et al., 2011; Munday et al., 2011; Cass et al., 2011; Bristow et al., 2012; Walker et al., 2015). What is not yet known is how this might work offshore, and whether such schemes can be effectively transferred. Our focus in this paper is to explore this. We acknowledge that 'benefits' might not just be economic, and that changes to aesthetics, pride, status, and other more intangible effects may be perceived by communities located near offshore renewable energy developments (Soma and Haggett, 2015). Our focus here however is primarily on the economic benefits that might be explicitly provided, and the forms in which they might be delivered.

With increasing interest in the emerging field of 'Energy Justice', community benefits also represent an opportunity to examine how justice - or injustice - dimensions of energy projects are conceptualised and realised in practice. Jenkins et al (2016: 174) note that: "Energy is a new centre of gravity for justice scholars" and internationally social scientists from diverse disciplines are now examining justice implications of energy policies and developments. Sovacool (2014: 15) contends that "how we distribute the benefits and burdens of energy systems is pre-eminently a concern for any society that aspires to be fair". Justice can be understood and pursued in a number of ways, for example energy developments can have implications for procedural justice; distributive justice and; 
recognitional justice (Aitken et al 2016a, Jenkins et al 2016). Procedural justice is concerned with decision-making processes and recognises that distributional injustices can arise from unfair processes through which they were created. Distributive justice is focussed primarily at outcomes and identifying where and how injustices are experienced and how they can be addressed. Recognitional justice considers who is represented or ignored and how underrepresented groups can be fully recognised.

Each of these forms of justice has relevance to community benefits. For example, procedural justice requires that communities be involved in processes for the creation, design, operation and governance of community benefits. Distributive justice seeks to address the uneven distribution of energy resources and their associated (positive and negative) impacts, to ensure fair and equitable outcomes (Eames and Hunt 2013).

Recognitional justice relates to the importance of ensuring that all members of a community (howsoever this is to be defined) are enabled to participate, or are adequately represented in processes relating to community benefits. As such community benefits relates to each of these areas and offers a valuable focus through which to examine what energy justice means and how it might be pursued in practice.

\section{Social acceptance, benefits, and offshore renewables}

There is an established literature on social acceptance and offshore renewables. Research has explicitly explored issues of impact and benefit, and suggested that while people may perceive that there are benefits from offshore renewables, to which they respond positively, they also believe there to be impacts about which they are concerned (Rudolph, 
2014; Ellis et al., 2007). Often this is framed as a spatial and temporal disjuncture; renewables may bring benefits in terms of clean energy, energy security, and investment, but are regarded as evoking immediate and more tangible burdens locally (de Groot and Bailey, 2016; Firestone and Kempton, 2007; Devine-Wright and Howes, 2010; Haggett, 2010b; Eames and Hunt 2013).

The disbenefits documented include concerns about local fisheries (in terms of loss of livelihood, skills and way of life, as well as impact on fish stocks) (Gray et al., 2005; Mackinson et al., 2006); impacts on bird populations and flight paths (OSPAR Commission 2004; Haggett, 2008); and negative effects on recreational activities including boating, fishing and yachting (Firestone and Kempton 2007; Haggett, 2010a). Concerns have also been noted about changes to the natural beauty and quality of the coastline in which a development is planned, and that it may not ' $\mathrm{fit}^{\prime}$ ' in with the ascribed characteristics and values of the coastal landscape (de Groot and Bailey, 2016; Lilley et al., 2010; Gee, 2010; Rudolph, 2014; Ladenburg and Dubgaard, 2009; Ladenburg, 2009; Ladenburg and Lutzeyer, 2012; McLachlan, 2009; Ellis et al., 2007; Haggett, 2008).

Further, research suggests that the development of an offshore project may be imbued with broader meaning than just the loss of particular material attributes. There may be consequences for the 'attachment' that people have to an area, and its symbolic value and meaning (Devine-Wright and Howes, 2010; Gee 2010; Rudolph 2014; Bishop and Miller, 2007). Responses to new developments are therefore a multi-dimensional phenomenon constituted through various, interrelated and context-specific, personal, social and 
structural factors (e.g. Devine-Wright 2005, Jobert et al., 2007; Wolsink, 2007; McLachlan, 2009; Devine-Wright, 2009; Wiersma \& Devine-Wright, 2014; Todt et al., 2011; Soma and Haggett, 2015).

Community benefits can represent a means to redress any perceived imbalance between the impacts and advantages from new developments, as well as reflecting procedural and recognitional forms of justice. Benefit-sharing is a concept used in international law as a way of responding to global environmental challenges in an equitable way, and is one which "holds significant promise. It is an attractive commitment that - even if vague in content and timeframe - raises expectations that we may directly address perceived injustices about access, ownership and/or control of resources that are perceived as [...] embodiments of community interests" (Morgera, 2014:2). Further, Wynberg and Hauck (2014:6) describe benefit-sharing as "a new way of approaching natural resource management and spreading the costs and benefits of using and conserving eco-systems and their resources across actors". Certainly, there is evidence to suggest that benefit schemes for renewables are popular. There are a range of community benefit models in place for onshore renewables (Aitken, 2010b; Cass et al., 2011; Cowell et al., 2011; Walker et al., 2015), which, if increased support and acceptance of a development was the aim, could be viewed as successful (Rudolph et al., 2015; Walker et al., 2014).

However, the effectiveness of these schemes depends upon their underlying motives, and the institutionalisation of their delivery. Apart from Scotland, where onshore wind farms pay $£ 5000$ per MW generated to the local community (Scottish Government, 2014), such schemes are usually non-standardised, non-institutionalised, locally varying, and voluntary 
gestures (Markantoni \& Aitken 2015). Aitken (2010b), Cass et al. (2010), and Walker et al. (2015) all suggest that an institutionalised, formalised and regulated provision of benefits may present them as a constitutional element of wind farm planning, and encourage support for such schemes. Walker et al. (2015:6) argue that an institutionalised provision of benefits can be regarded as "complying with policy rather than purposely trying to buy local acceptability". However, in turn, this can be re-interpreted as an attempted bribe from the government or a form of compensation (Aitken 2010b, Walker et al. 2015). Indeed, a common and cynical understanding of community benefits as bribery has been noted (Aitken, 2010b; Cass et al., 2010; Walker et al., 2014), along with an inadequate planning process for facilitating them (Strachan \& Jones, 2012). The motives for providing local benefits are often associated with the localised impacts, although developers often actively eschew impact rhetoric by stressing altruistic and good neighbour behaviour, social corporate responsibility, and the formation of community ties (Cass et al., 2010; DevineWright 2012). The underlying rationales for the provision of benefits therefore play a role in their effectiveness as much as the level of institutionalisation of the way in which they are delivered.

What has not yet been considered is how this might apply offshore. There are very few schemes in place, their design and implementation has been largely ad hoc, and there is as yet no detailed analysis of rationale or practice. This attention is required in particular because of the spatial challenges arising from considering community benefits for offshore developments: the distance between the location of a project and any beneficiaries, the difficulties of defining a relevant community, and the way in which impact is perceived. In 
what follows, we discuss these different challenges and develop a new typology for understanding them. We thus aim to provide the systematic and critical examination which Morgera (2014) argues is required, paying particular attention to the "different framings of the concept of benefit-sharing and their political motivations and implications" (Parks and Morgera 2015:1). In a key paper on this topic, they go on to suggest that the difficulty in doing so "lies in identifying the basis on which benefits should be shared as well as different understandings of what a benefit is and who the beneficiaries should be" (op cit). We therefore present a detailed exploration of precisely these ideas.

\section{Methods}

The empirical basis of this study utilised a multi-method approach, and drew on a range of primary and secondary data sources. The data collection identified international case studies that apply or propose various community benefits schemes. Our sampling method was that, rather than selecting particular cases, in the first instance we strove to find the population (Mason, 2002) through an online search, i.e. all the current cases of community benefits from offshore renewables. These cases identified are - as far as our searches revealed - the key cases of the development of community benefits from offshore renewables anywhere in the world, keeping in mind the challenges particularly related to language issues and the time frame of the study. The case studies were identified through documentation available online (e.g. websites, media coverage, reports, planning documents). Our search had no restrictions on geographic regions or language and included all types of offshore renewable energy projects. Our search identified 36 case studies of 
offshore renewables projects with existing or planned community benefits schemes, most of which were community benefit funds related to offshore wind farms in the UK.

Having identified these case studies, we examined the policy and existing practices in the relevant countries, and the detail of the particular cases of community benefits, to develop an understanding of the contexts in which they emerged. In particular this entailed examination of the UK, USA, Denmark, Germany and the Netherlands; countries which are relatively well advanced in their consideration of community benefits from offshore renewables, as well as South Korea, Ireland, and Canada. These existing schemes are predominantly connected to offshore wind, as the most advanced renewable energy source, but also included emerging wave and tidal energy projects.

We then explored the cases in more detail, conducting a search and analysis of data related to them, such as planning documents, project websites, newspaper articles, and press releases that gave evidence of any community benefit efforts. This extensive data collection was complemented with a small number of semi-structured interviews with ten key stakeholders including developers, local planners and community organisations. The selection of interviewees was mainly based on three case studies that went beyond the establishment of community funds in order to gather further knowledge about rationales and practicalities of these schemes. Thus, these interviewees were selected on the basis of interest (Patton, 1990); we did not undertake to interview a representative sample of wind farm developers, but focused on those developers actively involved in the design or delivery of offshore benefits (Morse, 1994). Given the novel nature of this field and the small 
number of innovative benefit schemes there was not a large population of potential interviewees, as such we focussed on key stakeholders relevant to the U.K. case studies. This enabled rich insights into the rationales underpinning community benefits schemes and experiences of these (Fielding and Thomas, 2008; Silverman, 2005). The interview schedule used was semi structured, allowing for a consistency of questioning, but flexibility to adapt to the particular case and interviewee (Kvale, 2007; May, 2001).

In a first step, our analysis was based on drawing out points of key significance and interest from across the case studies that we examined (Ely et al., 1991; Silverman, 2005), before subsequently exploring the particularities of some projects. The focus in the second step was on exploring why and how community benefits are delivered from offshore renewables; how community and benefit are defined; and the effects of these definitions. This is also reflected in this paper, as we aim to draw out these higher level points of synthesis, rather than focusing on the specifics of the particular case studies, except as examples of certain issues.

We conducted a content analysis on the extensive set of documentary material, and the interview data (MacDonald, 2008) exploring how and why community benefits were being delivered, and the challenges to doing so. The qualitative content analysis was aimed at a systematic screening and organisation of the material and was guided by predefined categories based on the research goals referring to the types of offshore renewables, types of benefits (e.g. material or monetary), delivery mechanisms, beneficiaries, spatial distribution and challenges, but also maintained some flexibility for creating subcategories 
and coding of previously unforeseen and unexpected elements of community benefits (e.g. different understandings of community benefits and the significance of impacts). A stringent data triangulation was deemed less gainful, due to a limited variety of data sources and existing community benefit schemes. Instead the authors drew on investigator triangulation (Flick 2007) in order to share individual interpretations of the data, the coding, and findings, and eventually to jointly discuss the patterns and conceptual links between benefits, beneficiaries and impacts that have emerged from the data.

\section{Conceptualisation of community benefits from offshore renewables}

Our research reveals a range of models to deliver benefits from offshore renewables. This includes direct voluntary monetary streams as well as indirect benefits that emerge from the development of particular projects and the wider establishment of an offshore renewables industry. Even if the latter cannot necessarily be considered as community benefits in the strictest sense, we include them as they can have features which may be interpreted as benefits for community and are also often considered as such in practice. Therefore, we suggest that not all the identified benefit models can be easily classified as voluntary benefit sharing, but relate to different understandings of community and benefit and impact that are employed in practice. The table in the appendix lists our categorisation of the different types of benefit schemes and their key features, and demonstrates the variety of benefit schemes used or proposed for offshore wind, wave and tidal projects. Our intention is not to describe the characteristics and values of each scheme but to uncover and analyse the varying and ambiguous understandings of community, benefit and 
perception of impact that have been used in their conceptualisation. Therefore, we refer to the categorisations we developed, and which are included in the table, as examples in our discussion below.

Based on our analysis of the case studies and different methods of benefit provision, we suggest that there are different motivations for providing benefits, delivered in different ways, with varying understandings of what constitutes a community, an impact, and a benefit. We find that, while the underlying understandings of benefits and community can be contested and are nebulous (Bristow et al., 2012; Strachan \& Jones, 2012), the way in which these concepts are defined influences the practical implementation of benefit schemes. We present this analysis in more detail below.

\subsection{Rationales for community benefits from offshore renewables}

The introduction of community benefits from offshore renewables is relatively new, and from our analysis of the cases we suggest it is delivered for a number of reasons:

(1) Voluntarism by developers reflects the motivation to act as a good neighbour as part of good practice of community engagement. Community benefit schemes from offshore renewables were first introduced by some developers in the UK for Round 1 projects in order to replicate schemes from onshore wind farms. Since there are no regulations, community benefit packages have been arranged on a voluntary basis between the developer and affected and close communities. Examples include UK offshore wind farms Rhyl Flats, Robin Rigg, North Hoyle, and Scroby Sands (see Appendix). 
(2) Much less commonly, community benefits can also be statutory conditions imposed (or suggested) by authorities, regulations could then be material considerations in the planning process. For example, a recently proposed scheme in Massachusetts legally obliges a developer to provide community benefits, in return for community support. This scheme is formalised through a "legally binding contract between a bidder and one or more community based organizations $(\mathrm{CBO})$ where the bidder has committed to provide specified community benefits and the CBO has committed in specific ways to support the project in the governmental approval process" (BOEM 2014). In Denmark, regulations state that at least $20 \%$ of the ownership of a wind farm should be offered to geographically local communities and adjacent municipalities (Anker \& Jørgensen, 2015), which also applies to nearshore sites that are currently being implemented for a tendering scheme. In Scotland, there is no legal obligation for developers to offer community benefits, but the Highland Council introduced the most advanced (but still voluntary policy) that guides contributions from developers and also regulates the distribution of benefit payments from offshore renewables (The Highland Council, 2014).

(3) Community benefits have also emerged as a direct response to pressure and demand from communities. The introduction of compulsory 'community benefit agreements' in Massachusetts resulted from community lobbying which "requested to BOEM that those communities most impacted by offshore wind farms development receive direct benefits from these projects" (Vinyard Power Cooperative 2014). Our interviews revealed a similar demand for community benefits that has also been brought forward locally in response to the Walney Offshore Wind Farm proposal in the UK. As we now discuss, these differing rationales affect the way the benefits are conceptualised and delivered. 


\subsection{Defining and understanding community benefits}

Our analysis suggests that there are at least five different ways in which benefits from offshore renewables are being defined and understood in practice:

(1) An understanding of spreading the positive relates to distributive justice and is rooted in ideas of sharing the economic benefits of harnessing a nation's natural resources and assets (Wynberg and Hauck, 2014; Morgera, 2014). For example, Scotland has some of the best offshore wind, wave, and tidal resources in the world, and developers providing benefits when they access these resources is a way of spreading the rewards that they bring. This reflects the fundamental understanding of the Scottish Government, which defines community benefits as "voluntary measures" which do not directly serve a planning purpose (Scottish Government, 2012) but allow for "communities across the country to share in benefits from its rich natural resource" (Scottish Government, 2014:3).

(2) The provision of benefits can also be understood as a way of recognising hosts (recognitional justice). Here, benefits can be perceived as payments by developers to acknowledge that communities are 'hosting' a development. This 'hosting' may also take place onshore, and attests to the locality of particular onshore developments, such as the substation. This understanding follows the model onshore, where "communities close to terrestrial wind farms typically receive payments in recognition that they are hosting developments of national importance in their locality" (interview with UK developer). Discussions about benefits may take place as part of a comprehensive engagement process, in which the developer is seen as a 'good neighbour' who cares about and is committed to a community (Cass et al., 2010; Aitken et al., 2016b). This was affirmed by developers we 
interviewed who framed the provision of community benefits as corporate social responsibility, and part of developing and applying good practice principles.

(3) Providing benefits to communities may be perceived as a way of increasing local acceptance and support (Cowell et al., 2011; Morgera, 2014). Indeed, the agreement in Massachusetts is that community groups who receive benefits must commit to support the project. UK developers in our research also described voluntary benefits as a means of keeping a community onboard, and a strategic way to compete with other developers. Of course, acceptance of community benefits is related to the willingness to accept environmental and social change more generally (Kerr et al., 2014), may not necessarily lead to more support for the actual project, and may again be perceived as a bribe (Aitken 2010b; Cass et al., 2010; Walker et al., 2014).

(4) Benefits may be used to account for an impact, acknowledging tangible local disbenefits, and addressing this. Research has long pointed to a perceived disjuncture between the global benefits of renewable energy and impacts experienced locally (Bell et al, 2005; Haggett, 2010a) relating to distributive justice. One developer explicitly highlighted that they consider impacts of the projects during operation and construction to define the eligibility for funding. There may also be demand from communities for any impact to be taken into account. For example by referring to the Walney Offshore Wind Farm local councillors argued that "no one should underestimate the need for communities to get due recompense" (North-West Evening Mail, 2013). The Highland Council also considers benefits as important "in respect of development, such as large renewable energy schemes, which have a long term impact on the environment", and to ensure that local communities "are 
compensated for the disruption and inconvenience associated with large scale development work" (The Highland Council, 2014).

(5) Finally, benefits are also sometimes referred to as compensation for an identified and agreed loss. However community benefit payments should not be confused with compensatory payments, which are enforced legally to mitigate losses for or impacts on relevant third parties that are caused by offshore development, such as fishers or environmental organisations. These are explicitly outside our research remit.

As indicated, these understandings of benefits can become somewhat intertwined in practice. However, the different definitions matter - because they influence the way in which 'communities' are defined and understood, as discussed in the next section.

\subsection{Definition of beneficiary communities}

Defining 'community' in terms of providing benefits is not straightforward (Bristow et al., 2012). This becomes even more complex for offshore renewables where the offshore sites and communities are spatially separated, and physical proximity may be an unhelpful way of thinking about determinants not only for public acceptance (Devine-Wright 2012) but also for beneficiary communities. Our analysis suggests that the ways in which 'benefits' and 'community' are understood are interlinked and have important implications for how community benefits are conceptualised and operationalised (and defining communities improperly can lead to procedural or recognitional injustices). In the context of offshore wind farms we propose the following definitions of communities as the recipients of benefits: 
(1) Similar to benefits from onshore wind farms, communities of locality can be regarded as a certain group of people dwelling in the geographical vicinity of a renewable energy development (Walker, 2011; Strachan \& Jones, 2012). A community of locality is defined by spatial and jurisdictional criteria and has been the most common approach for defining communities across our case studies. However, due to the likely visibility of an offshore development from various communities along the coast, benefits based on a spatial rationale are often directed to either a smaller number of coastal communities (e.g. the North Hoyle Community Fund), or a local authority region that benefits from funds (e.g. the Sheringham Shoal Community Fund). Mirroring new regulations designed to increase the acceptance of onshore wind farms, the current tender for nearshore wind farms in Denmark also earmarks an obligatory ownership of $20 \%$ for the residents close to the development as well as coastal municipalities (Anker \& Jørgensen 2015).

(2) An all-embracing community involves an indirect and spatially detached distribution of possible benefits among a number of diverse communities or a wider area that is not necessarily affected by a particular offshore development. In this approach, local authorities are usually in charge of spreading revenues from offshore renewables, which may prioritise certain groups or communities. This understanding was taken even further by one developer we interviewed, who suggested that all people who pay electricity bills fund wind farm projects and could therefore be considered for the distribution of benefits. This may, however, result in beneficiary communities that do not correspond with affected or host communities, may benefit larger, distant or many communities, and could provoke questions about distributional fairness. 
(3) Communities of interest are communities constituted through a common interest in or whose interests are affected by the development of offshore renewables. Such a community of interest could include particular stakeholders in the vicinity of a development whose activities share the same space, such as recreational users (Strachan \& Jones, 2012). (4) Benefits to mitigate any adverse effects may be made available to particular groups or communities who are negatively impacted by defining them as affected communities. An impact may relate to a development offshore, or the distance between communities and onshore developments of an offshore project. This definition has been applied by RWE for some of their projects, such as the Triton Knoll Offshore Wind Farm, and the planned East Anglia ONE wind farm. Likewise, initial community benefits from London Array were related to the onshore substation and the O\&M base at Ramsgate rather than the offshore developments which are $20 \mathrm{~km}$ out at sea. In general, developers in our research found it easier to demarcate affected communities by means of the physical onshore developments. (5) Finally, community can also refer to local, charitable, public or community organisations that act as a category of the public, such as community councils or development trusts (Walker, 2011). Such community organisations usually represent a rather dispersed area which is not necessarily limited to coastal proximity and administer the spatial allocation of benefit revenues or benefit payments.

Our analysis finds evidence for all these conceptualisations of communities, but it also became evident that the question about an adequate definition of eligible communities is closely linked to the definition of benefits. Even more so, we suggest that there is a direct relationship between the understanding of benefit, the definition of a community, and the perception of impact (as illustrated in Figure 1): 
Figure 1: The relationship between community, benefit, and impact

This relationship has been drawn as a triangle rather than a flow diagram because each of the definitions and understandings can influence each other. As such, the first step in conceptualising community benefits, or developing a community benefits strategy, could be informed by any one of the three factors. In turn, how each is conceived will have implications for the others and if any one consideration is given primacy this will play a key role in shaping how community benefits are developed and deployed. For example, if the understanding of benefits is about spreading the positives from a nation's natural resources, then this influences the definition of community that will be used. This is less about impacts on a particular affected community; instead a spatially detached 'all embracing' definition of community becomes the most relevant understanding, as shown in Figure 2.

Figure 2: The relationship between community, benefit, and impact for the spreading and sharing of benefits from national resources

A generally positive perception of offshore renewables as providing a range of benefits, rather than negative impacts, for communities can influence the framing of benefits as being about spreading the advantages of national resources. Similarly, conceiving of communities in a broad, non-localised or geographically specific sense can influence a perception of benefits as being a way of providing a national benefit very widely. This set of 
understandings is usually drawn upon by governments and local authorities, and reflects the Scottish Government's understanding of the provision of community benefits. Examples of communities and benefits being defined in this way include schemes of a quasi-equal distribution of revenues, such as the Coastal Communities Fund (see Appendix).

A second way of understanding the relationship between communities, impacts, and benefits is not to consider positive benefits from projects nationally,, but how these positive benefits might be delivered locally. The focus is therefore the role of the developer as a 'good neighbour', acknowledging the hosting of local communities, and spreading benefits to them:

Figure 3: Relationship between community, benefit, and impact for acknowledging hosts

In this understanding, benefits are a way of recognising that a community is a host, and a developer acts as a good neighbour, engaging in principles of corporate social responsibility. These understandings were most commonly used in our research by developers who recognise a general local impact of their activities, and who attempt to create benefits locally that act as balance to this (and which would not be available without the existence of the project). Examples of benefits being conceived of and delivered in this way include education programmes, skills and training schemes, as well as indirect benefits delivered through the supply chain and tourism, such as particular developer practices regarding 
London Array and Gwynt y Mor offshore wind farms, and the Sound of Islay Tidal project (see Appendix).

If however, benefits are understood as a way of accounting for impact, then this also influences the definition of community (fig. 4):

Figure 4: The relationship between community, benefit, and impact when accounting for negative impact

In this understanding, communities are perceived to suffer a negative impact, for example from being near the onshore infrastructure or experiencing place-related disruptions, and benefits are a way of accounting for this. They are then purposively targeted at a specific community which is deemed to be affected. This set of understandings is often drawn upon by communities, as exemplified by coastal communities close to the Walney offshore wind farm project or the Vinyard Power Co-operative in the US. Examples of community benefits schemes being conceived of and delivered in this way include the establishment of certain community funds and one-off payments and direct investments in local communities, such as the Dudgeon Community Support Fund and the Triton Knoll and Gwynt Y Mor community benefit funds.

If benefits are understood as a way of increasing support or mitigating opposition, then yet another definition of community is likely to be employed: 
Figure 5: Relationship between community, benefit, and impact for increasing local support in local communities

This is a set of understandings which are perhaps used more implicitly than explicitly, with the exception of the Massachusetts scheme, where support is expected from the community in exchange for benefits. This model supposes a sceptical view of a public, and perhaps an assumption that support cannot be ensured through other means. It does, of course, risk accusations of bribery, which can themselves undermine the success of such a model (Aitken, 2010a; Cass et al., 2010; Walker et al., 2014). The 'community' in this model may be a community of locality; or communities of interest or community organisations, whereby particular groups are the recipients of support or benefit, to try and ensure their support (or lack of opposition).

In summary, whilst other factors or variables will inevitably influence how community benefits are conceived, our findings therefore suggest that these factors (Definition of Community; Understanding of Benefit; Perception of Impact) appear to be the three principal considerations influencing the design and conceptualisation of community benefits for offshore renewables.

\section{The balance of costs and benefits}

The different understandings of the role of benefits are related to whether they were perceived to be a way of spreading the benefit that would come from a project; or adding 
an additional cost to it. Research on onshore renewables finds that processes of public consultation are sometimes considered as costly in terms of time and money by developers, which ignores both the more general benefits that a supportive public can have, as well as the greater likelihood of success for a specific project (Aitken et al., 2014). We suggest that a similar sentiment may be relevant here, and a reluctance by some developers to consider community benefits for three reasons.

Firstly, some developers were cautious about supporting community benefits at all because of the nascent state of the offshore industry. Many respondents pointed to the uncertain and risky financial circumstances of developing offshore renewables. One interviewee stressed that "how much is available for a community fund is very uncertain for some developers".

Secondly, there was doubt about whether benefits could be afforded. In the UK, the changing institutional framework for funding the development of offshore wind farms provides increased uncertainly about this. The previous Renewables Obligations Certificates (ROC) system through which existing on- and offshore wind farms have been funded provided some certainty as to how much money would be generated per unit of energy, how much income the wind farm would generate and how much could be spent on community benefits. This system was replaced and new offshore projects will require a 'Contract for Difference' for which companies compete to build a project at the lowest cost, whereby the UK government provides support for the cheapest project. As one developer commented, such efforts by the UK Government to have wind farms built as cheaply as 
possible to provide cheaper energy for consumers may actually discourage the provision of community benefits.

This applies a fortiori to tidal and wave projects that are less advanced than offshore wind and not yet commercially viable in the UK. Some developers therefore argued that tidal projects need to be considered separately from offshore wind. There are some tidal projects that explicitly take community benefits into account (see Appendix): Wyre Tidal Energy, West Islay, Sound of Islay, Swansea Bay, Solway Energy Gateway in the UK, and Sihwa Tidal project in South Korea. However, since most tidal energy projects are still in the very early planning stages, current considerations of community benefits mostly include the exploration of appropriate approaches to enable communities to benefit from these projects, without any preferences towards particular models or definitions. Indeed, developers in our research suggested that providing specific benefits might financially harm projects and the development of a tidal energy industry.

Thirdly, we found evidence of a conceptual division between indirect benefits and direct community benefit schemes being employed to challenge the idea of the necessity of additional community benefits from emerging offshore renewables industry. Some respondents challenged the idea of beneficiary communities because, for example, the whole of Scotland can be seen as a profiteer of a growing offshore renewables industry benefitting from indirect mechanisms, such as job creation, supply chain benefits and tax revenues. These indirect benefits may indeed be experienced locally, for example through the use and maintenance of harbours, increased trade in onshore towns, and use of local 
labour. However, the extent to which this might be realised is still in debate. The impact of local economic side-effects from onshore wind farms may be () modest, in the absence of benefit-sharing mechanisms (Munday et al., 2011; Ejdemo \& Søderholm, 2015). The ongoing development of offshore renewables means economic opportunities through indirect 'trickle down' effects are not fully understood (Kerr et al., 2014). We therefore found that the conceptualisation of impact and benefit comprises both an uncertainty about whether benefits could be afforded, and a reluctance to add any extra costs to a development. In this calculation, the 'costs' of the benefit are balanced against the support that it might engender. The point is that the conceptualisation of benefit as mitigating an impact, or trying to increase public support (which may be impossible to predict or deliver) is a very different and distinct way of envisaging communities, impacts, and benefits.

\section{Discussion: interrelated understandings}

While the most common definition of a community is a geographical proximate locality, as we have demonstrated, for offshore projects the notion of a host or potentially affected community is not easily determined in spatial terms. It requires more flexible and innovative criteria for definition. This provides some leeway for defining and demarcating both beneficiaries and the mechanisms of how benefit streams are established and distributed; and is one of the reasons why most developers tend to reject a more standardised and formalised approach to community benefit. 
Furthermore, and in addition to spatial considerations, the role of impacts has come to the fore as the second central element in the definition of beneficiary communities and the eligibility of benefit sharing. However, 'impacts' often carry a negative connotation. While the very idea of sharing benefits may be grounded in altruistic principles, the perception of impacts therefore emerges as an intermediate step for defining communities, as well as the rationale for providing benefits. This is reflected in the references to affected communities and the accounting for impacts that have been applied to rationalise the provision of community benefits. There is some potential for impacts to be defined in a more positive way (for example, from the positive benefits that communities could experience which would not otherwise be available to them). The very lack of regulations for community benefits grants developers some leeway for rationalising and defining communities and benefits. This allows for both interpretations, accounting for negative impacts and good neighbour practices. It does mean that a non-formalised approach to community benefits may not only produce a discrepancy within the rationales underlying the questions why benefits are provided and also how beneficiary communities are demarcated, but also between potentially impacted and benefitting communities.

Our research has explored the different understandings of community benefits, and suggested they may be difficult to deliver. The concept of spreading a national benefit may be well intentioned, but unachievable if it cannot be afforded; a reluctant approach to beneficiaries which uses the underlying rationale of trying to increase community support may be ineffective. As discussed above, previous research on social acceptance and offshore renewables has explicated different impacts, and the disjuncture between local disbenefit and inter/national benefit, that may be associated with the development of 
offshore renewables. Considering past research on the broader sense of change that a development can bring supports our suggestion that simply understanding impact in terms of the loss of particular material attributes and, consequently, considering benefit just as a recompense for this, may not be sufficient. There is evidence from research on community benefits from onshore renewable to suggest that schemes which are seen as attempting to 'buy' support are not well received. Our analysis suggests alternative ways of conceiving of benefits, and provides a tool for the discussion about the most appropriate way to consider them in each case.

\section{Conclusion - Learning points and good practices}

Our research has explored the complexity of defining and delivering community benefits from offshore renewables. It also highlights how some of these complexities and challenges resonance with broader discussions about energy justice. Community benefits represents an opportunity to realise distributive justice addressing unequal impacts of energy developments, procedural justice through participation of communities in planning, operation and governance of community benefits and recognitional justice in both processes and outcomes. The many different ways that community benefits are conceptualised and pursued reflect these various possible outcomes but also highlight the challenges associated with pursuing energy justice.

While there are also non-monetary and less tangible benefits for communities, such as the enhancement of local distinctiveness due to novel projects (Devine-Wright, 2011), we focused here on the delivery of economic benefits in terms of a monetary redistribution of 
developer profits, as this was the remit of our research, and reflects the bulk of current benefit-sharing mechanisms in practice. We have demonstrated, as Parks and Morgera (2015:2) outlined, that there are "different understandings of what a benefit is and who the beneficiaries should be", and have further demonstrated the affect that this has. On the basis of our findings, we suggest the following points warrant consideration in the planning and implementation of benefits from offshore renewables.

There is currently very little guidance in place, anywhere, about community benefits from offshore renewable. However, on the basis of our research, we would caution against the development of prescriptive or specific criteria. There is unlikely to be a single approach that fits all projects. We suggest therefore that community benefit schemes should be tailored to the needs of the local context and characteristics of the site and project, instead of being determined by standardised methods. However, more guidance on the available options is nevertheless desirable, and developers and local authorities should clarify the meaning and limitations of community benefits when entering negotiations with relevant communities. A reflection upon the interrelationship between all three dimensions (community, benefit, impacts) can provide a robust approach in developing community benefit models, and ensure that relevant communities, in each case, are included.

In developing clearer guidance, consideration should be given to the emerging state of the industry. The delivery of benefits is subject to the financial means of the developer. Financial security in terms of revenues from the offshore development is a vital condition for the provision of benefits. In the UK, there is some concern that the new 'Contract for 
Difference' scheme may hamper the opportunity to provide voluntary community benefits and discourage developers to do so since competitive bidding leads to a focus on lowering costs. Community benefits may therefore not be included unless they are required as part of the bidding scheme. However, similar to the defining element of impact, such a requirement would contravene the idea of voluntary distribution of community benefits and does not appeal to most of the developers in our research. Developers should therefore be urged to consider, reveal, discuss and justify openly what is achievable and expectable in terms of community benefits when engaging local communities. This should be part of ongoing engagement processes with communities (Aitken et al., 2016b). We suggest that benefits which are just considered as a way of capturing support are likely to be ineffective in doing so. Parks and Morgera (2015:3) argue that "benefit-sharing can be used as a semantic sticking plaster for harmful practices, as a superficial means to garner social acceptability". Such a conceptualisation of benefits is likely to achieve the converse effect.

Our research also follows Parks and Morgera's (2015:2-3) argument that benefit-sharing should not only refer to the tangible distribution of resources, but "also to the processes leading to decisions to exploit natural resources and share benefits. Prior informed consent and participatory processes about what benefits should be shared and how are therefore encompassed in this understanding". It is for this reason that we advocate effective consultation with all parties about the rationale, scope, and delivery of any benefits. They should be seen as part of an ongoing process, rather than the end in themselves. Previous research on public consultation about on- and offshore wind farms, found that early engagement is key (Aitken et al., 2014). Likewise, the preparation of particular benefit 
models should be undertaken at the earliest possible stage and in a joint process with local stakeholders. Early and thorough engagement with local communities should be a first step for assessing the needs and concerns of communities, but also for discussing appropriate and desired benefit models. Parks and Morgera (2015:1) argue that an evaluation of benefit-sharing requires an investigation mapping the "different framings of the concept of benefit-sharing and their political motivations and implications". Ultimately, the definition and provision of benefits takes place under these auspices - whether conceived of as a national good to be distributed or a means to mitigate opposition - and we have sought to demonstrate in this paper the impact that the different formulations have. 


\section{References:}

Aitken M, 2010a, "Why we still don't understand the social aspects of wind power: A critique of key assumptions within the literature" Energy Policy 38(4), 1834-1841.

Aitken M, 2010b, "Wind power and community benefits: Challenges and opportunities" Energy Policy 38(10) 6066-6075

Aitken M, Haggett C, \& Rudolph D, 2014, “Wind Farms Community Engagement Good Practice Review" Research Report commissioned by ClimateXChange for the Scottish Government, www.climatexchange.org.uk/reducing-emissions/what-good-communityengagement-wind-farm-developments

Aitken, M., Christman, B., Bonaventura, M., Horst, D. V. D., \& Holbrook, J., 2016a, “Climate Justice Begins at Home: Conceptual, Pragmatic and Transformative Approaches to Climate Justice in Scotland" Scottish Affairs, 25(2), 225-252.

Aitken, M., Haggett, C., \& Rudolph, D., 2016b, “Practices and rationales of community engagement with wind farms: awareness raising, consultation, empowerment". Planning Theory \& Practice, 1-20.

Anker H T, Jørgensen M L, 2015, Mapping of the legal framework for siting of wind turbines: Denmark. Frederiksberg: Department of Food and Resource Economics, University of Copenhagen (IFRO Report; No. 239)

Bell D, Gray T, and Haggett C, 2005, “Policy, participation and the 'social gap' in wind farm siting decisions", Environmental Politics 4, 460-477

Bishop I, Miller D, 2007, "Visual assessment of off-shore wind turbines: the influence of distance, contrast, movement and social variables" Renewable Energy 32(5) 8114-8131 
BOEM, 2014 Massachusetts Proposed Sales Notice presentation by J Stromberg (http://www.boem.gov/BOEM-MA-Auction-Seminar-PSN-Overview-Presentation/)

Bristow G, Cowell R, Munday M, 2011, "Windfalls for whom? The evolving notion of 'community' in community benefit provisions from wind farms" Geoforum 43(6) 11081120

Cass N, Walker G, Devine-Wright P, 2010, “Good Neighbours, Public Relations and Bribes: The Politics and Perception of Community Benefit Provision in Renewable Energy Development in the UK" Journal of Environmental Policy \& Planning 12(3) 255-275

Cowell R, Bristow G, Munday M, 2011, “Acceptance, acceptability and environmental justice: The role of community benefits in wind energy development" Journal of Environmental Planning and Management 54(4) 539-557.

Devine-Wright P, 2005, "Beyond NIMBYism: towards an integrated framework for understanding public perceptions of wind energy" Wind Energy 8 125-139

Devine-Wright P, 2009, "Rethinking NIMBYism: The Role of Place Attachment and Place Identity in Explaining Place-protective Action" Journal of Community \& Applied Social Psychology 19(6) 426-441

Devine-Wright $P$, Howes $Y, 2010$, “Disruption to place attachment and the protection of restorative environments: A wind energy case study" Journal of Environmental Psychology 30(3) 271-280

Devine-Wright P, 2011, "Enhancing local distinctiveness fosters public acceptance of tidal energy: a UK case study" Energy Policy 39 83-93 
Devine-Wright P, 2012, "Fostering Public Engagement in Wind Energy Development: The Role of Intermediaries and Community Benefits" in Learning from Wind Power: Governance, Societal and Policy Perspectives on Sustainable Energy Eds J Szarka, R Cowell, G Ellis, P Strachan, C Warren (Palgrave Mamillan, Basingstoke) pp 194-214

Eames, M. \& Hunt, M., 2013, “Energy justice in sustainability transitions research" in K. Bickerstaff, G. Walker, H. Bulkeley (Eds.), Energy Justice in a Changing Climate: Social Equity and Low-carbon Energy, Zed books, London (2013)

Ejdemo T, Söderholm P, 2015, “Wind power, regional development and benefit-sharing: The case of Northern Sweden" Energy and Sustainable Energy Reviews 47 476-485

Ellis G, Barry J, Robinson C, 2007, “Many ways to say 'no', different ways to say 'yes': Applying Q-Methodology to understand public acceptance of wind farm proposals" Journal of Environmental Planning and Management 50(4), 517-551

Ely M, Anzul M, Friedman T, Garner D, McCormack-Steinmetz A, 1991, Doing Qualitative Research: Circles Within Circles (Falmer Press, London)

Fielding N, Thomas, H, 2008, "Qualitative Interviewing" in Researching Social Life Ed N Gilbert (Los Angeles, Sage) pp 245-265

Firestone J, Kempton W, 2007, “Public opinion about large offshore wind power: underlying factors" Energy Policy 35(3) 584-598

Firestone J, Kempton W, Krueger A, 2009, “Public acceptance of offshore wind power project in the USA" Wind Energy 12 183-202

Flick U, 2007, Managing Quality in Qualitative Research (London, SAGE) 
Gee K, 2010, "Offshore wind power development as affected by seascape values on the German North Sea coast" Land Use Policy 27(2) 185-194

Gray T, Haggett C, Bell D, 2005, "Offshore wind farms and commercial fisheries in the UK: A study in stakeholder consultation" Ethics, Place \& Environment 8(2) 127-140

De Groot J, Bailey I, 2016, "What drives attitudes towards marine renewable energy in island communities?" International Journal of Marine Energy 13 80-95.

Haggett C, 2008, "Over the see and far away? A consideration of planning, politics, and public perceptions of offshore wind farms" Journal of Environmental Policy and Planning 10(3) 289-306

Haggett C, 2010a, "Public perceptions of offshore wind energy" Energy Policy 39(2) 503-510 Haggett C, 2010b, “A Call for Clarity and a Review of the Empirical Evidence: Comment on Feldman and Turner's 'Why Not NIMBY'” Ethics, Place \& Environment 13(3), 313-316 Jenkins, K., McCauley, D., Heffron, R., Stephan, H., \& Rehner, R., 2016, “Energy justice: A conceptual review" Energy Research \& Social Science 11: 174-182.

Jobert A, Laborgne P, Mimler S, 2007, "Local acceptance of wind energy: Factors of success identified in French and German case studies" Energy Policy 35(5) 2751-2760

Kermagoret C, Levrel H, Carlier A, 2014, "The Impact and Compensation of Offshore Wind Farm Development: Analysing the Institutional Discourse from a French Case Study" Scottish Geographical Journal 130(3) 188-206

Kerr S, Watts L, Colton J, Convey F, Hull A, Johnson K, Jude S, Kannen A, MacDougall S, McLachlan C, Potts T, Vergunst J, 2014, “Establishing an agenda for social studies research in marine renewable energy" Energy Policy 67 694-702 
Kvale S, 1996, Interviews: An Introduction to Qualitative Research Interviewing (London, Sage)

Ladenburg J, 2009, "Visual impact assessment of offshore wind farms and prior experience" Applied Energy 86(3) 380-387

Ladenburg J, Dubgaard A, 2009, "Preferences of coastal zone user groups regarding the siting of offshore wind farms" Ocean and Coastal Management 52(5) 233-242

Ladenburg J, Lutzeyer S, 2012, "The economics of visual disamenity reductions of offshore wind farms - Review and suggestions from an emerging field" Renewable and Sustainable Energy Reviews 16(9) 6793-6802

Lilley M B, Firestone J, Kempton W, 2010, "The Effect of Wind Power Installations on Coastal Tourism" Energies 3 1-22

Mackinson S, Curtis H, Brown R, McTaggart K, Taylor N, Neville S, Rogers S, 2006, “A report on the perception of the fishing industry into the potential socio-economic impacts of offshore wind farms", CEFAS Science Series Technical Report no. 133

MacDonald K, 2008, "Using Documents", in Researching Social Life Ed N Gilbert (Los Angeles, Sage) pp 285-303

Markantoni M, Aitken M, 2015, “Getting low-carbon governance right: learning from actors involved in Community Benefits" Local Environment (forthcoming)

Mason J, 2002, Qualitative researching (London, Sage)

May T, 2001, Social research: issues, methods and process (Buckinghamshire, Open University) 
McLachlan C, 2009, "'You don't do a chemistry experiment in your best china': Symbolic interpretations of place and technology in a wave energy case" Energy Policy 37(12) $5342-5350$

Morgera E, 2014, “Conceptualizing Benefit-Sharing as the Pursuit of Equity in Addressing Global Environmental Challenges", Research Paper No. 2014/41, Edinburgh School of Law, University of Edinburgh, and part of the project "BENELEX: Benefit-sharing for an equitable transition to the green economy -the role of law", www.benelex.ed.ac.uk) funded by the European Research Council Starting Grant, http://papers.ssrn.com/sol3/papers

Munday M, Bristow G, Cowell R, 2011, "Wind farms in rural areas: how far do community benefits from wind farm represent a local economic development opportunity" Journal of Rural Studies 27(1) 1-12

North-West Evening Mail, 2013, "Vow to help Barrow reap benefits of giant wind farm" 22 Oct http://www.nwemail.co.uk/news/vow-to-help-barrow-reap-benefits-of-giantwindfarm-1.1092928

OSPAR Commission, 2004, "Problems and benefits associated with the development of offshore wind-farms", Biodiversity Series http://cvi.se/uploads/pdf/Kunskapsdatabas\%20miljo/Flora\%20och\%20fauna/Faglar/utre dningar/p00212_Wind\%20farms_Problems\%20and\%20benefits.pdf

Parks L, Morgera E, 2015, “An interdisciplinary model for mapping the normative diffusion of fair and equitable benefit-sharing", University of Edinburgh School of Law Research Paper 2015/22 and BENELEX Working Paper N. 7 part of the project “BENELEX: Benefitsharing for an equitable transition to the green economy -the role of law" 
(www.benelex.ed.ac.uk) funded by the European Research Council Starting Grant, http://papers.ssrn.com/sol3/papers

Rudolph D, 2014, "The Resurgent Conflict Between Offshore Wind Farms and Tourism: Underlying Storylines" Scottish Geographical Journal 130(3) 168-187

Rudolph D, Haggett C, Aitken M, 2015 Community Benefits from Offshore Renewables: Good Practice Review (University of Edinburgh, on behalf of ClimateXChange)

Scottish Government, 2012 Planning Obligations and Good Neighbour Agreements. Circular 3/2012 http://www.scotland.gov.uk/Resource/0041/00410382.pdf

Scottish Government, 2014 Good Practice Principles for Community Benefits from Onshore Renewable Energy Developments Produced by Local Energy Scotland on behalf of The Scottish Government, http://www.localenergyscotland.org/good-practice/onshorecommunity-benefit/

Scottish Government, 2015 Good Practice Principles for Community Benefits from Offshore Renewable Energy Developments Produced by Local Energy Scotland on behalf of The Scottish Government October 2015, http://www.localenergyscotland.org/media/77721/Good-Practice-Principles-forOffshore-Community-Benefits.pdf

Silverman D, 2005, Doing qualitative research: a practical handbook (London, Sage)

Soma K, Haggett C, 2015, Enhancing social acceptance in marine governance in Europe, Ocean and Coastal Management 117 61-68 
Sovacool, B. K., 2014, "What are we doing here? Analyzing fifteen years of energy scholarship and proposing a social science research agenda" Energy Research \& Social Science 1: 1-29.

Strachan P A, Jones R J, 2012, "Navigating a Minefield? Wind Power and Local Community Benefit Funds" in Learning from Wind Power: Governance, Societal and Policy Perspectives on Sustainable Energy Eds J Szarka, R Cowell, G Ellis, P Strachan, C Warren (Palgrave Mamillan, Basingstoke) pp 174-193

The Highland Council, 2014, Community Benefit, http://www.highland.gov.uk/info/198/planning__long_term_and_area_policies/639/community_benefit

Todt O, Gonzales I M, Estevez B, 2011, "Conflict in the Sea of Trafalgar: offshore wind energy and its context" Wind Energy 14 699-706

Toke D, Breukers S, Wolsink M, 2008, "Wind power deployment outcomes: How can we account for the differences?" Renewable and Sustainable Energy Reviews 12(4) 11291147

Vinyard Power Cooperative, 2014 Offshore wind power, http://www.vineyardpower.com/offshore-wind

Walker G, 2011, "The role of 'community' om carbon governance" WIREs Climate Change 2(5) 777-782

Walker B J A, Wiersma B, Bailey E, 2014, "Community benefits, framing and the social acceptance of offshore wind farms: An experimental study in England" Energy Research \& Social Science 3 46-54 
Walker B J A, Russel D, Kurz T, 2015, “Communtiy Benefits or Community Bribes? An Experimental Analysis of Strategies for Managing Community Perceptions of Bribery Surrounding the Siting of Renewable Energy Projects" Environment and Behaviour (forthcoming)

Wiersma B, \& Devine-Wright P, 2014, “Public Engagement with offshore renewable energy: a critical review" WIREs Climate Change 5(4) 493-507

Wolsink M, 2007, "Planning of renewables schemes: deliberative and fair decision-making on landscape issues instead of reproachful accusations of non-cooperation" Energy Policy 35(5) 2692-2704

Wynberg R, Hauck M, 2014, "People, power, and the coast: a conceptual framework for understanding and implementing benefit sharing" Ecology and Society 19(1) 27 